\title{
PERANAN PERENCANAAN KEPERAWATAN DAN IMPLEMENTASI DI DALAM PEMBERIAN ASUHAN KEPERAWATAN \\ DI RUANG RAWAT INAP
}

\author{
Salsabila Mumtaza Nasution \\ mumtazanasution@gmail.com
}

\section{LATAR BELAKANG}

Proses keperawatan adalah suatu sistem yang mengatur perencanaan di dalam pelayanan kesehatan yang dimulai dari tahap pengkajian sampai tahap evaluasi yang dilakukan berdasarkan kaidah keperawatan. Salah satu tahap di dalam proses keperawatan adalah perencanaan keperawatan. Perencanaan keperawatan adalah penyusunan rencana tindakan keperawatan yang akan dilakukan perawat di dalam mengatasi permasalahan sesuai dengan diagnosis yang telah di tentukan dengan tujuan terpenuhinya kesehatan pasien. Perencanaan keperawatan dilakukan perawat di dasarkan oleh pengetahuan dan penilaian klinis agar mendapatkan hasil yang diharapkan. perencanaan keperawatan juga menentukan atau berpengaruh terhadap proses keperawatan selanjutnya, sehingga harus dilakukan dengan segala pertimbangan berdasarkan teori-teori yang ada.

Perencanaan keperawatan dilakukan sebagai penentuan langkah-langkah didalam pemecahan masalah seperti perumusan tujuan, rencana tindakan, serta penilaian asuhan keperawatan yang telah dilakukan kepada pasien. Pengkajian keperawataan ini merupakan strategi untuk mencegah, mengurangi, dan mengkoreksi permasalahan yang telah diidentifikasi sebelumnya pada tahap diagnosa keperawatan.

Perencanan keperawatan disusun dan dirumuskan oleh perawat bersama keluarga atau orang terdekat pasien agar keberhasilan asuhan keperawatan dapat ditingkatkan. Sehingga perawat harus mampu memberikan penjelasan terkait perencanaan asuhan keperawatan agar keluarga atau orang terdekat pasien dapat diajak bekerja sama.

Dalam melakukan tugasnya, perawat menempati posisi terdepan dari sitem pelayanan kesehatan di ruang rawat inap, karena perawatlah yang secara terus menerus selama 24 jam memantau keadaan pasien. Dengan demikian, perawat mempunyai andil besar di dalam peningkatan pelayanan mutu rumah sakit. Oleh karena itu, jika proses asuhan keperawatan 
tidak dilaksanakan dengan baik maka mutu pelayanan rumah sakit pun menjadi kurang baik pula.

Rencana keperawatan yang disusun perawat kepada pasien akan berbeda setiap pasiennya. Oleh karena itu, setap pasien di ruang rawat inap akan memiliki rencana keperawatan yang berbeda, meskipun berada di satu ruangan yang sama, karena tiap pasien dapat memiliki keluhan yang berbeda. Perawat terlebih dahulu harus mampu untuk mengkaji keluhan-keluhan yang ada, menentukan diagnosa, dan setelah itu baru dapat menyusun rencana keperawatan.

Tahap lainnya dari proses keperawatan adalah implementasi. Implementasi adalah pengelolaan dan perwujudan dari rencana keperawatan yang telah perawat susun pada tahap perencanan. Sehingga antara perencanaan dan implementasi mempunyai hubungan yang sangat erat. Pelaksanaan rencana tindakan yang ditentukan mempunyai tujuan agar kebutuhan pasien terpenuhi secara maksimal yang mencakup aspek peningkatan, pencegahan, pemeliharaan serta pemulihan kesehatan.

\section{METODE}

Metode yang digunakan dalam penulisan ini adalah dengan pendekatan studi pustaka. Data-data diperoleh dari literasi berbagai sumber seperti buku, tesis, dan jurnal. Data-data yang terkumpul kemudian dibandingkan dan di analisis. Analisis ini dilakukan dengan cara menemukan peranan dari perencanaan keperawatan yang dilakukan perawat di ruang rawat inap. Setelah analisa dilakukan, tiap-tiap sumber akan dilihat perbedaannya dan akan diambil suatu hasil. Hasil dari perbandingan dan analisis tersebut disatukan menjadi satu pembahasan yang terstruktur.

\section{HASIL}

Hasil dari perbandingan dan analisis dari berbagai literatur yang telah dibaca adalah perencanaan keperawatan disusun setelah tujuan dan hasil yang diharapkan telah ditetapkan. Perencanaan keperawatan adalah tindakan yang di rancang untuk membantu pasien dalam mengatasi masalah-masalah yang dimilikinya agar pasien dapat beralih dari tingkat kesehatan saat ini ke tingkat kesehatan yang diinginkan sesuai hasil yang diharapkan bersama. Sedangkan implementasi adalah pelaksanaan tindakan perencanaan keperawatan yang dilakukan perawat setelah sebelumnya menyusun rencana tindakan. Perencanaan dan implementasi terbukti mampu mengatasi masalah yang ada didalam pemberian asuhan 
keperawatan di ruang rawat inap. Oleh karena itu perencanaan dan implementasi ini merupakan suatu proses penting didalam asuhan keperawatan.

Penyusunan rencana keperawatan bekerjasama dengan keluarga. rencana keperawatan juga dikomunikasikan dengan tim kesehatan untuk meningkatkan pendekatan ketika bekerja dengan keluarga untuk mencapai hasil yang di harapkan. Keluarga berhak dan bertanggungjawab untuk membuat keputusan kesehatan mereka sendiri. Penempatan rencana asuhan keperawatan mengikuti pilihan bersama yang dirancang untuk mencapai tujuan yang telah ditetapkan.

Rencana tindakan keperawatan terdiri dari tujuan umum, tujuan khusus, dan rencana tindakan keperawatan. Perencanaan menggambarkan tindakan yang akan dilakukan dengan merujuk pada NCI (Nursing Intervention Classification). Rencana tindakan keperawatan membagi karakteristik tindakan berupa: konseling/psikoterapeutik, pendidikan kesehatan, perawatan mandiri dan ADI, terapi modalitas keperawatan, perawatan berkelanjutan, kolaborasi terapi somatis dan psikofarmaka (Stuart, GW dan Sundeen, SJ, 2006)

Dari jurnal yang telah dibaca, di dalam perencanaan keperawatan perawat jarang mengalami kesulitan dalam melakukannya. Hal ini dikarenakan proses perencanaan yang disusun sudah mengacu kepada panduan yang sudah tersedia di tiap rumah sakit. Panduan tersebut berupa lembar intervensi keperawatan berdasarkan tiap diagnosa keperawatan yang telah ditentukan. Tetapi lain halnya dengan implementasi, perawat cenderung merasa kesulitan dalam melakukannya. Implementasi merupakan pelaksanaan dari perencanaan keperawatan yang telah di susun. Perawat cenderung mengeluhkan bahwa tahap implementasi sangat menguras tenaga.

Setelah perawat menyusun rencana asuhan keperawatan, perawat pun mengimplementasikan asuhan keperawatan. Tak selesai disitu, perawat juga harus membandingkan respon pasien terhadap outcome yang telah direncanakan dan menggunakan informasi tersebut untuk mereview kembali apakah asuhan keperawatan yang telah dilakukan sudah mencapai tujuan atau tidak.

Salah satu dari perencanaan keperawatan yang disusun perawat pada ruang rawat inap adalah pemeriksaan tanda-tanda vital untuk mengetahui perubahan keadaan umum,monitor frekuensi, kedalaman napas dan bunyi napas tambahan pasien, memberi posisi semi fowler pada pasien yang membutuhkan, dan masih banyak contoh bentuk perencanaan keperawatan 
lainnya. Salah satu implementasi keperawatan yang dilakukan adalah menggali perasaan, berfikir positif, mengidentifikasi aspek positif diri yang masih dapat dilakukan sesuai kemampuan, dan memilih target realistis yang dapat tercapai.

Dalam pelaksanaan implementasi dan perencanaan keperawatan, perawat dituntut untuk mempunyai kemampuan kognitif (intelektual), kemampuan dalam hubungan interpersonal, dan keterampilan dalam melakukan tindakan. Proses implementasi haruslah berpusat pada kebutuhan klien, faktor-faktor lain yang mempengaaruhi kebutuhan keperawatan, strategi implementasi keperawatan, dan kegiatan komunikasi. (Kozier et.al., 1995).

\section{PEMBAHASAN}

Perencanaan keperawatan disusun bergantung dan berdasarkan dari hasil pengkajian. Setelah melewati tahap pengkajian, maka setiap asuhan keperawatan dilanjutkan dengan analisis dan pengelompokkan secara sistematik terhadap data bjektif maupun subjektif untuk merumuskan diagnosis keperawatan, yang terfokus pada dua hal, yaitu: 1) status kesehatan klien, 2) kekuatan pasien yang menggambarkan

Komponen perencanaan keperawatan menurut (Nursalam, 2012), adalah :

a. Prioritas masalah dengan kriteria : masalah-masalah yang mengancam kehidupan merupakan prioritas pertama, masalah-masalah yang mengancam kesehatan seseorang adalah prioritas kedua, masalah-masalah yang mempengaruhi perilaku merupakan prioritas ketiga.

Menurut Marquis \& Huston, perubahan yang tidak terduga yang telah terjadi atau apabila mendapatkan informasi baru dari pasien yang dapat mengubah rencana awal, maka perawat dapat kembali menetapkan prioritas baru atau menyesuaikan prioritas berdasarkan siatuasi yang sedang berlangsung.

b. Tujuan asuhan keperawatan dengan kriteria : spesifik, bisa diukur, bisa dicapai, realistik, ada batas waktu.

Dengan menentukan tujuan dan kriteria hasil diharapkan asuhan keperawatan yang diberikan akan memberikan keberhasilan sesuai dengan tujuan yang diharapkan klien maupun perawat. 
c. Rencana tindakan dengan kriteria : disusun berdasarkan tujuan asuhan keperawatan, melibatkan pasien/keluarga, mempertimbangkan latar belakang budaya pasien/keluarga, menentukan alternative tindakan yang tepat, mempertimbangkan kebijaksanaan dan peraturan yang berlaku, lingkungan, sumberdaya dan fasilitas yang ada, menjamin rasa aman dan nyaman bagi pasien, kalimat instruksi, ringkas, tegas dengan bahasanya mudah dimengerti

Menurut (PPNI, 2009), rencana tindakan keperawatan dikembangkan berdasarkan diagnosis keperawatan, mencakup:

a. Kriteria struktur: tatanan praktik menyediakan: 1) sarana yang dibutuhkan dalam perencanaan keperawatan, 2) adanya mekanisme pencatatan dan perencanaan sehingga dapat digunakan kembali dikomunikasikan

b. Kriteria proses: perencanaan terdiri dari penetapan prioritas masalah, tujuan, dan rencana tindakan keperawatan. Bekerjasama dengan klien dalam menyusun rencana tindakan keperawatan. Perencanaan bersifat individual (sebagai individu, kelmpok, dan masyarakat) sesuai dengan kondisi atau kebutuhan lain

c. Kriteria hasil:

1. Tersusunnya rencana asuhan keperawatan

2. Perencanaan mencerminkan penyelesaianterhadap diagnosis keperawatan

3. Perencanaan tertulis dalam format yang singkat dan mudah di fahami

4. Perencanaan menunjukkan bukti adanya revisi pencapaian tujuan (PPNI, 2009)

Proses perencanaan meliputi perumusan tujuan dan menentukan intervensi yang tepat. Proses ini dimulai dengan membuat daftar semua masalah-masalah pasien dan mencari masukan dari pasien, keluarga atau orang terdekat pasien tentang penentuan tujuan akhir yang dapat diterima dan dapat dicapai secara rasional. Pernyataan tujuan akhir harus dinyatakan dalam bentuk pernyataan yang dapat diukur, yang secara obyektif menunjukann perkembangan terhadap pemecahan masalah yang ditemukan. Bagian lain dari perecanaan keperawatan adalah menentukan intervensi yang digunakan perawat dengan melibatkan pasien dan keluarga untuk mencapai tujuan yang telah ditetapkan (Nursalam, 2007).

Rencana asuhan keperawatan harus dibuat secara spesifik, jelas, jangka waktu ditentukan, dapat diukur baik kognitif, afektif, dan psikomotor. Jenis intervensi keperawatan 
harus mencantumkan therapi keperawatan, pendidikan kesehatan, kolaborasi dengan Tim kesehatan lain, observasi dan monitoring.

Perawat di dalam memberikan asuhan keperawatan harus mempunyai perencanaan waktu di dalam melakukan tindakannya. Adanya perencanaan waktu dibutuhkan untuk mencapai tujuan awal yang telah ditetapkan, mendisiplinkan diri perawat, dapat berpikir kritis dan dapat meningkatkan tingkat keberhasilan asuhan keperawatan. Pada ruangan rawat inap, perawat yang bertugas harus terlihat selalu siap akan perubahan kondisi pasien atau jika ada informasi baru. Dengan mempunyai perencanaan waktu yang ideal, perawat dapat mengambil dan memperkirakan suatu keputusan dengan baik dan efektif.

Pelaksanaan (implementasi) adalah pengelolaan dan perwujudan dari rencana keperawatan yang telah di susun pada tahap perencanaan (Butcher, 2012). Pada tahap implementasi keperawatan, perawat memerlukan tenaga dan fokus yang paling tinggi karena berhubungan dengan tindakan invasif terhadap pasien.

Menurut (PPNI, 2009), perawat mengimplementasikan tindakan yang telah diidentifikasikasi dalam rencana asuhan keperawatan yang mencakup:

a. Rasional: perawat mengimplementasikan rencana asuhan keperawatan untuk mencapai tujuan yang telah ditetapkan .

b. Kriteria struktur: Tatanan praktik menyediakan: sumber daya untuk pelaksana kegiatan, pola ketenagakerjaan yang sesuai kebutuhan, adanya mekanisme untuk mengkaji dan merevisi pola ketenangan secara periodik, melakukan supervisi terhadap tenaga pelaksana keperawatan di bawah tanggung jawabnya, menjadi koordinator pelayanan dan advokasi terhadap klien untuk mencapai tujuan kesehatan, menginformasikan kepada pasien tentang status kesehatan dan fasilitasfasilitas pelayanan kesehatan yang ada, memberikan pendidikan pada klien dan keluarga mengenai konsep dan keterampilan asuhan diri serta membantu klien memodifikasi lingkungan yang digunakan, mengkaji ulang dan merevisi pelaksanaan tindakan keperawatan berdasarkan respon klien.

c. Kriteria hasil: terdokumentasi tindakan keperawatan dan respon klien secara sistematik dan dengan mudah diperoleh kembali, tindakan keperaawatan dapat diterima oleh klien dan keluarga, ada bukti-bukti yang terukur tentang pencapaian tujuan (PPNI, 2009) 
Metode-metode implementasi diantaranya adalah:

1) Membantu dalam aktivitas kehidupan sehari-hari (AKS), aktivitas tersebut mencakup ambulansi, makan, berpakaian, mandi,menyikat gigi, dan berhias. Kondisi yang mengakibatkan kebutuhan AKS dapat bersifat aakut, kronis, temporer, maupun permanen. Sebagai contoh, pasien pasca operasi yang tidak mampu secara mandiri menyelesaikan semua AKS.

2) Konseling. Konseling merupakan metode implementasi yang membantu pasien menggunakan proses penyesuaian masalah untuk mengenali dan menangani stress dan yang memudahkan hubungan interpersonal di antara pasien, keluarganya, dan tim perawatan kesehatan.

3) Penyuluhan. Digunakan dengan menyajikan prinsip, prosedur, dan teknik yang tepat tentang perawatan kesehatan untuk pasien dan untuk menginformasikan pasien tentang status kesehatannya

4) Memberikan asuhan keperawatan langsung untuk mencapai tujuan terapeutik pasien, perawat melakukan intervensi untuk mengurangi resiko yang merugikan dengan menggunakan tindakan pencegahan dan preventif dalam memberikan asuhan.

\section{PENUTUPAN}

a. kesimpulan

Berdasarkan hasil dari kajian ini, dapat disimpulkan bahwa perencanaan keperawatan dan implementasi mempunyai peranan penting didalam melakukan asuhan keperawatan kepada pasien di ruang rawat inap. Perencanaan keperawatan adalah salah satu dari proses keperawatan yang dilakukan dengan menyusun rencana tindakan yang akan dilakukan dalam rangka mengatasi masalah-masalah pasien. Sedangkan implementasi adalah pelaksanaan dari rencana keperawatan yang telah disusun, dan implementasi ini adalah sebagai hasil dari perencanaan, apakah perencanaan yang telah disusun efektif atau tidak.

b. saran

Untuk kedepannya, penulis berharap agar perawat memiliki pengetahuan yang lebih baik lagi mengenai asuhan keperawatan. Sehingga tidak ada kendala di dalam melaksanakan proses-proses keperawatan. Dan mengingat peranan perencanaan keperawatan dan implementasi ini, diharapkan juga perawat di dalam pelaksanaannya dapat melaksanakan dengan sebaik-baiknya. 


\section{DAFTAR PUSTAKA}

Anggeria, E., Maria. (2018). Hubungan Supervisi Dengan Pelaksanaan Asuhan Keperawatan di Ruang Rawat Inap Lantai 10 Rumah Sakit Umum Royal Prima Medan Tahun 2017. Jurnal JUMANTIK, 3(2), 78-97.

Butar-Butar, J., \& Simamora, R. H. (2016). Hubungan Mutu Pelayanan Keperawatan dengan Tingkat Kepuasan Pasien Rawat Inap di RSUD Pandan Kabupaten Tapanuli Tengah. Jurnal Ners Indonesia, 6(1), 50-63.

Kholifah, Siti Nur. 2017. Model Asuhan Keperawatan Keluarga Berbasis Nursing Relatinal Capital terhadap Kemandirian Keluarga Dengan Hipertensi di Wilayah Kota Surabaya. (Doctoral dissertasion, disertasi FKM Airlangga, Tidak dipublikasikan).

Kusnadi, N. (2017). Analisis Kelengkapan Dokumentasi Keperawatan di Ruang Rawat Inap Non Intensive Rumah Sakit X. Jurnal Bidang Ilmu Kesehatan, 9, 553-562

Muhith, A. (2015). Pendidikan Keperawatan Jiwa. Yogyakarta: Andi Offset.

Nogo, A. (2014). Kinerja Perawat Dalam Penerapan Standar Asuhan Keperawatan di Rumah Sakit Umum Daerah Naibonat Kabupaten Kupang. Jurnal Penelitian, 18, 62-66.

Pusdik SDM Kesehatan. (2016). Dokumentasi Keperawatan. Jakarta Selatan: Penulis.

Simamora, R. H. (2005). Hubungan Persepsi Perawat Pelaksana Terhadap Penerapan Fungsi Pengorganisasian Yang Dilakukan Oleh Kepala Ruangan Dengan Kinerjanya Diruang Rawat Inap RSUD Koja Jakarta Utara (Doctoral dissertation, Tesis FIK UI, Tidak dipublikasikan).

Sunaryo, Wijayanti, R., Kuhu, M. M., dkk. (2015). Asuhan Keperawatan Gerontik. Yogyakarta: Andi Offset

Ummah, T., Wardani, I., Hargiana, G. (2018). Asuhan Keperawatan Psikososial: Ketidakberdayaan Pada Klien Dengan Gagal Jantung. Jurnal Keperawatan, 10(2), 138-142.

Wijaya, C. P. (2016). Pengaruh Burnout Syndrome Terhadap Proses Asuhan Keperawatan (Studi Pada Perawat Rumah Sakit Medika Utama Blitar). Jurnal Ilmu Manajemen, 5(3), 2336. 
Yusuf, M., (2013). Hubungan Manajemen Waktu Perawat Pelaksana Dengan

Pendokumentasian Asuhan Keperawatan di Ruang Rawat Inap Kelas III Rumah Sakit Umum Daerah Dr. Zainoel Abidin Tahun 2013. Jurnal Ilmu Keperawatan, 1(1), 76-84.

Yusuh, H. A., Saini, S. Awaluddin, S. W. (2019). Asuhan Keperawatan Pemenuhan

Kebutuhan Oksigenasi Pada Pasien Asma Bronkhial di RSUD. Haji Makassar. Jurnal Media Keperawatan, 10. 